\title{
FINANCIAL MECHANISM OF THE SOCIO-ORIENTED ECONOMIC DEVELOPMENT OF THE BLACK SEA REGION
}

\author{
Marianna Stehnei ${ }^{1}$, Inna Irtysheva ${ }^{2}$, Olena Gurina ${ }^{3}$
}

\begin{abstract}
The aim of the article is to study the current state of financial provision of the social sphere of the Black Sea region and to develop practical recommendations for its optimization in conditions of decentralization processes. Methodology. We have made a generalization of the theoretical provisions of the financial mechanism of the social sphere of the region. We propose to investigate the financial mechanism of the social sphere of the Black Sea region by means of analysis of indicators of income and expenditure parts of the budget of regions of the Black Sea region. At the present stage of the gradual transformation of the socio-economic development of the regions and in the context of the implementation of the budget decentralization reform, a number of acute problems from the financial support of social development, the guarantee of social standards for the population, and the improvement of the quality of social services arose. The solution of these problems needs a substantial research in the direction of developing the best models for financing social development of the regions, which will promote the achievement of decent social standards and stimulate economic growth. The financial mechanism for providing social development of the Black Sea region is analysed, the current state of the regional budget in terms and trends in financing social expenditures of the region is identified. It is determined that despite the increase in tax revenues, local authorities still do not have sufficient financial resources to perform their functions and tasks. It adversely affects the development of social infrastructure, provision of social services, and does not contribute to the effective human development, which serves not only as the main goal but also as a key determinant of the economic development of the region. It is substantiated that in order to improve the situation in the social sphere of the region, it is necessary to improve the financial mechanism of social security. On the basis of the investigated scientific approaches, the concept of "mechanism of the financial provision of socially-oriented regional development" is clarified, directions of budget and extrabudgetary financing of social expenditures are substantiated, and proposals on the improvement of financial management of social sphere in the conditions of decentralization are developed. Results. To improve the system of financial provision of social development of the region, it was proposed to establish clear and transparent financial relations in the areas of income generation and distribution of regional budget expenditures at all levels, to create conditions for additional attraction of financial resources from extrabudgetary sources aimed at the implementation of regional social programs, and to form an effective system control over the functioning of the financial mechanism, primarily on the part of the territorial communities. Value/originality. The concept of the mechanism of the financial provision of socially-oriented regional development is generalized. An estimation of the social sphere of the Black Sea region is carried out on the basis of the analysis of indicators of income and expenditure parts of budgets of regions of the Black Sea region, the use of which allows determining the perspective directions of the social sphere of the Black Sea region.
\end{abstract}

Key words: social sphere, financial support mechanism, regional budget, social expenditures, extra budgetary sources, decentralization.

JEL Classification: H53, H61

\footnotetext{
Corresponding author:

${ }^{1}$ Mukachevo State University, Ukraine.

E-mail: stegneym@gmail.com

${ }^{2}$ Admiral Makarov National University of Shipbuilding, Ukraine.

E-mail: innauamd@gmail.com

${ }^{3}$ V.O. Sukhomlynskyi National University of Mykolaiv, Ukraine.

E-mail: gurina@gmail.com
} 


\section{Introduction}

At the present stage of the gradual transformation of the socio-economic development of regions and in the context of the implementation of the budget decentralization reform, there are a number of acute problems associated with the financial support of social development, guaranteeing social standards for the population, and improving the quality of social services. The problems are also aggravated by the general economic crisis, military actions in the east, and considerable political turbulence, which led to chronic budget deficits, underfunding of social programs, and aggravation of social crises. The solution of these problems requires substantial research in the direction of developing the best models for financing the social development of regions, which will promote the achievement of decent social standards and stimulate economic growth.

Problems of financing the social sphere of Ukrainian regions in modern conditions are the subject of research by many Ukrainian scholars, among them are O. L. Shcherbakova, O. V. Stepanova, N. Pihul, O. Liuta, A. Boiko, O. Zhuk, Ya. Honcharuk, T. Bashynskyi. A special attention of researchers is focused on the formation of effective mechanisms for the financial provision of social development of regions in the context of the implementation of the budget decentralization reform. Scholars have developed a number of mechanisms for optimizing budget financing of social development, substantiated alternative sources of financial support for the implementation of individual social programs.

Today, the basic preconditions for financial and administrative decentralization of the regions of Ukraine are laid down, which, with proper implementation of the initiated reforms, will contribute to the development of the social sphere. At the same time, the current state of the social sphere of the Black Sea region requires indepth research in the direction of optimizing the financial mechanism of socially-oriented development, which defines the purpose, objective, and subject of our study.

\section{Problems and disadvantages of the social development financing system}

At the present stage of the gradual transformation of the socio-economic development of regions and in the context of the implementation of the budget decentralization reform, there are a number of acute problems related to the financial support of social development, guaranteeing social standards for the population, and improving the quality of social services. The problems are also aggravated by the general economic crisis, military actions in the east, and considerable political turbulence, which led to chronic budget deficits, under-funding of social programs, and aggravation of social crises. In this context, appropriate is the opinion of O. V. Stepanova that "the modern branch of social protection enters into a new social reality with a distorted mechanism of decentralized management and financing, which is not ensured by a real increase in the financial capacity of communities and the introduction of the necessary new tools. In the extreme contradiction, there are approaches to financing the provision of social assistance and support, based on the needs and belonging to a certain vulnerable category of population. The reason for this problem situation is the discrepancy of the current model of financing the social protection system of the population to the modern socio-economic context" (Stepanova, 2016).

The current state of social security and the permanent exacerbation of financial problems of social development point to the imperfection of the existing system of administrative and territorial organization and functioning of local self-government bodies, the ineffectiveness of the distribution of powers between the state and regions, and the imperfect mechanism for the formation and distribution of financial resources. Today, regional authorities and local governments are in a situation where simultaneously it is necessary to create conditions for the balanced economic development of territories under significant market turbulence and unpredictability and independently solve most of the acute social problems. An effective factor in stabilizing the situation at the local level should be the effective formation of local budgets, which can make local communities financially independent and capable of solving emerging socioeconomic problems at their own expense.

To date, local authorities do not have sufficient financial resources to manage the economy and social sphere at their own level. Ya. Hocharuk and O. Kushlak consider the main reasons for such a situation are the following:

- high level of concentration of financial resources in the state budget of the country, which prevents regional and local budgets from solving vital issues for the population;

- regulated incomes play a dominant role in the structure of revenues to regional and local budgets, while the share of own and assigned to the areas tax payments remains low;

- the absence of significant income sources in the composition of incomes not taken into account in the calculation of transfers (Honcharuk \& Kushlak, 2012).

\section{Reform of decentralization in the social sphere}

Reform in the sphere of decentralization is an important factor in promoting the social and economic development of regions and, in particular, extends the powers of regional management in the field of social security and the development of appropriate social policy. According to the Cabinet of Ministers of 
Ukraine, the basic package of new legislation has already been formed and is in operation, and priority legislative initiatives are being implemented in the direction of implementation of the reform, including:

- Laws on amendments to the Tax and Budget Codes of Ukraine. Due to these changes, financial decentralization began. In particular, local budgets for the period of 2014-2017 grew by 2.7 times (by 123.4 billion UAH), while the share of local budgets in the consolidated budget of Ukraine - by $5.6 \%$ from $45.6 \%$ in 2014 to $51.2 \%$ by the end of 2017 .

- The Law "On Voluntary Association of Territorial Communities" has created favourable conditions for the formation of a capable basic level of local self-government. As of 2018, 753 united territorial communities, consisting of 3492 former local councils have already been created. Now more than 6.5 million people live in united territorial communities;

- The Law "On Cooperation of Territorial Communities" regulates the mechanism of solving common problems of communities, including the development of social infrastructure, waste recycling and disposal, the use of water resources, etc. The mechanism created was already used by 861 communities and 199 agreements were signed.

- The Law "On Fundamentals of State Regional Policy" broadens the rights of regional authorities in the area of the planning of socio-economic development, diversification of financing sources for regional programs, interregional and international cooperation. Since the beginning of the reform, the volume of state support for regional development and community infrastructure development has increased 39 times ( 0.5 billion in 2014 to 19.37 billion UAH in 2018).

- Law "On Amendments to Certain Legislative Acts of Ukraine on the Decentralization of Authority in the Field of Architectural and Construction Control and Improvement of Urban Planning Legislation”. 100 cities, including 11 UTCs, were vested with the new urban planning authority.

- Array of laws to extend the powers of local selfgovernment bodies and optimize the provision of administrative services allowed to delegate to the bodies of local self-government the appropriate level of authority to provide basic administrative services: registration of a place of residence, issuance of passport documents, state registration of legal and natural persons, entrepreneurs, registration of acts of civil status, property rights, land issues, etc. (Kabinet Ministriv Ukrayiny, 2017).

Thus, one of the most important components of the regional policy in the field of social security and public protection is the financial mechanism for the implementation of the respective powers. In the economic literature, there is no consensus on the economic essence and components of the financial mechanism of social security in the region.

\section{Financial mechanism of social protection}

O. B. Zhuk proposes to understand the financial mechanism of social protection of the population as the totality of methods, tools, and levers of accumulation, redistribution, and use of financial resources, specially developed, legally established, and defined by socio-economic policy, with the corresponding organizational and legal support in order to improve the general welfare of the population (Zhuk, 2017). The author also considered in detail the sources of financing of social protection in Ukraine, among which the main ones are: the state budget, budgets of administrative-territorial units, specialized funds, non-budgetary funds, donations and charitable contributions.

Similar positions are taken by the authors N. Pihul, O. Liuta, and A. Boiko, who consider financial mechanisms of securing the social sphere as an integral system of organization of financial relations, which include appropriate forms, methods, and instruments for their implementation, in the process of mobilizing and distributing financial resources for the purpose of creating conditions for the effective functioning of the social sphere in Ukraine on the basis of solving the corresponding tasks caused by the social functions of the state (Pihul \& Boiko, 2015).

The most developed, in our opinion, is the definition of financial support for the social development of the region by $\mathrm{O}$. Shcherbakova, which the author suggests to understand "a set of measures aimed at mobilizing existing and identifying and attracting potential financial resources of development management entities of a certain administrative-territorial unit, as well as resources of external investors, and the formation, by means of their consolidation, of a financial basis for the implementation of economic processes in the respective territory, the implementation of the planned social programs, projects, supporting the stable functioning of the infrastructure, and improving the regional living environment" (Shcherbakova, 2012). Researchers also substantiate the potential opportunities for financial support for social development by expanding sources of extrabudgetary financing, among which the most promising ones are self-financing, lending, targeted investment, and other forms of financial security.

On the basis of the generalization of the conducted researches, we will further understand the mechanism of financial provision of socially-oriented regional development as a complex system of horizontal and vertical financial relations, which contributes to the formation of optimally combined and economically balanced sources and directions of financing of social needs of the population in accordance with state standards and socio-economic development goals of the region. 


\section{Analysis of indicators of financial support for social development}

In the context of the implementation of the decentralization reform, the reallocation of revenues and expenditures between the state and local budgets is gradually being conducted with the corresponding transfer of responsibility for the financing of the social sphere to the local level. In particular, during 2015-2017, the government has consistently transferred to the local level the administration of the following types of taxes: personal income tax $(75 \%)$, land tax $(100 \%)$, single tax (100\%), excise tax (5\%), real estate tax (100\%), income $\operatorname{tax}(10 \%)$, state duty (10\%), $100 \%$ fee for the provision of administrative services, $80 \%$ of the environmental tax. This led to a corresponding increase in the revenue side of local budgets. Only in the period of 2015-2016, tax revenues to regional budgets increased by an average of $50 \%$. Table 1 shows the volume of tax revenues to local budgets by regions of the Black Sea region.

For the period of 2016-2017, growth was slightly lower, in particular, in the Mykolaiv $(+23 \%)$, Odesa $(+29 \%)$, and Kherson region $(+10.2 \%)$. The main source of the revenue part of the regional budgets is still the personal income tax, which is distributed in such proportions: $60 \%$ - city (village), $15 \%$ - the regional level, and $25 \%$ - the state budget. The tax on personal income is still the largest source of city and regional budgets. In 2016, the overall share of tax revenues in the regional budgets of the Black Sea region amounted to an average of $81 \%$. At the same time, the main source of their filling was the personal income tax $(61 \%$ on average in the region). Along with this, problematic issues of administering the income tax at the regional level remain a significant shadowing of real incomes of individuals and the unregulated issue of regional binding of incomes of citizens of the region and social costs. That is, the tax on personal income is paid by the citizen at the place of work, and citizens receive local budget expenditures at their place of residence, which in some way contributes to the imbalance of income and expenditure. Exit from the situation at the level of territorial communities is seen only by increasing the number of jobs in the territory.

The analysis of budget revenues by the regions of the Black Sea region showed that there is a problem of significant differentiation of tax revenues and other revenues of local budgets (without intergovernmental transfers) per capita of the existing population (Table 2).

In 2016, the overall gap between the revenues of local budgets per capita in terms of regions of the Black Sea region amounted to an average of $30 \%$. The highest revenues of the budget are characteristic for the Odesa region, where the volume of income (including transfers) per capita amounted to $11920 \mathrm{UAH}$, and the lowest is in Kherson region - $8270 \mathrm{UAH}$. In the structure of incomes, about $40 \%$ are tax revenues, in which the share of local

Table 1

Own revenues of local budgets in terms of regions of the Black Sea region, thousand UAH

\begin{tabular}{|l|c|c|c|c|c|}
\hline \multicolumn{1}{|c|}{ Regions } & 2015 & 2016 & gain, \% & 2017 & gain, \% \\
\hline Mykolaiv region & 2942972,50 & 4338753,00 & 47,42758 & 5354247 & 23,41 \\
\hline Odesa region & 6939798,25 & 10763161,00 & 55,09328 & 13966161,00 & 29,76 \\
\hline Kherson region & 2273071,50 & 3300013,80 & 45,17862 & 4036509,9 & 22,20 \\
\hline
\end{tabular}

Source: according to data of Odesa, Mykolaiv, and Kherson regional councils

Table 2

Separate indicators of the revenue part of budgets in terms of regions of the Black Sea region per capita of the existing population, UAH

\begin{tabular}{|c|c|c|c|c|c|c|c|c|c|}
\hline \multirow[b]{2}{*}{ Indicator } & \multicolumn{2}{|c|}{ Mykolaiv region } & \multirow[b]{2}{*}{ Gain, \% } & \multicolumn{2}{|c|}{ Odesa region } & \multirow[b]{2}{*}{ Gain, \% } & \multicolumn{2}{|c|}{ Kherson region } & \multirow[b]{2}{*}{ Gain, \% } \\
\hline & 2014 & 2016 & & 2014 & 2016 & & 2014 & 2016 & \\
\hline 1. Local taxes & 165,67 & 927,91 & 460 & 212,9 & 1271,5 & 497 & 149,50 & 851,69 & 470 \\
\hline$\%$ in the structure & 3,7 & 9,5 & 6 & 4,2 & 10,7 & 6 & 4,1 & 10,3 & 6 \\
\hline 2. Tax revenues & 1838,12 & 3284,13 & 79 & 1957,6 & 3844,5 & 96 & 1372,9 & 2607,5 & 90 \\
\hline$\%$ in the structure & 40,9 & 33,64 & -7 & 38,5 & 32,3 & -6 & 38,0 & 31,5 & -7 \\
\hline 3. Subvention from the state budget & 3,12 & 76,65 & 2357 & 3,99 & 69,76 & 1648 & 4,62 & 61,49 & 1231 \\
\hline$\%$ in the structure & 0,07 & 0,79 & 0,7 & 0,08 & 0,59 & 1 & 0,13 & 0,74 & 1 \\
\hline 4. Single tax & 152,75 & 408,13 & 167 & 192,3 & 462,10 & 140 & 134,8 & 409,91 & 204 \\
\hline$\%$ in the structure & 3,4 & 4,2 & 0,8 & 3,7 & 3,9 & 0 & 3,7 & 5 & 1 \\
\hline 5. Revenues without transfers & 2074,44 & 3779,24 & 82 & 2339,9 & 4513,4 & 93 & 1711,2 & 3130,9 & 83 \\
\hline$\%$ in the structure & 46,2 & 38,7 & -8 & 46,1 & 37,9 & -8 & 47,4 & 37,9 & -10 \\
\hline 6. Own non-tax revenues & 257,42 & 1285,6 & 399 & 374,43 & 1758,8 & 370 & 235,37 & 1209,3 & 414 \\
\hline$\%$ in the structure & 5,7 & 13,2 & 7 & 7,4 & 14,8 & 7 & 6,5 & 14,6 & 8 \\
\hline Total income per capita & 4491,5 & 9761,7 & 117 & 5081,2 & 11920 & 135 & 3608,4 & 8270,8 & 129 \\
\hline
\end{tabular}

Source: calculated by the authors based on the data of the State Treasury Service 
taxes increased by an average of $7 \%$. For the period of 2014-2016, the amount of subventions from the state budget per capita in the region increased by a thousand times from 2357\% (Odesa region) to 1231\% (Kherson region). A significant increase in the amount of subventions from the state budget for fulfilling social obligations is primarily associated with the growth of the minimum wage almost 2 times and higher prices for housing and communal services. Among the positive trends, we can note the growth of own non-tax revenues in the studied regions and the increase in tax revenues from local taxes.

Despite the increase in tax revenues, local authorities still have insufficient financial resources to fulfil their functions and tasks. In addition, in 2017 there was a reduction in the financing of certain social expenditures for education from the central budget (the financing of salaries remains the responsibility of the state budget, and a part of vocational education institutions transferred entirely to the balance of regional budgets and budgets of territorial communities), health care (the state budget guaranteed salaries of medical personnel, provision of medical products and equipment according to the list, and financing of general government programs). Aligning the financial capacity of local budgets to guarantee the provision of social benefits and assistance in the regions is carried out through targeted subsidies (Kabinet Ministriv Ukrayiny, 2017).

Of course, the general concept of budget support for local self-government is logical and appropriate. However, the permanent increase in energy prices against the background of the transfer of responsibility in the area of financing public utilities and energy sources of social institutions to the local level leads to the reduction of such institutions at the local level, the reduction of social services, the violation of training schedules over the significant increase in vacations, stop or significant reduction in the number of culture and sport facilities. In addition, a significant reduction of staff in social institutions, the introduction of paid services, etc. also have negative social consequences.

In these conditions, of course, the dependence of the social sphere of the region on its economic independence and economic development increases due to the additional filling of local budgets, a part of which is directed towards the implementation of social programs. An important principle of the social policy of the state is the convergence of the main indicators of social security of the regions of Ukraine with the aim of equal access of all citizens to the provision of social services of guaranteed social security and raising of living standards. At the same time, in terms of decentralization, different regions have different opportunities for implementing social policy measures and different priorities for the role of social development in the regional strategy.

Thus, the mechanism of financing of the regional economic development in the conditions of socialization involves the full and balanced use of direct and indirect methods of ensuring social development. First of all, direct methods include:

- financing of guaranteed social benefits and expenditures through budgets of all levels and separate target funds; - mixed financing of social programs of the region; - direct investment in human capital development and social infrastructure development.

First of all, indirect methods include stimulating the development of the region's economy and job creation, stimulating the social consciousness of business leaders, expanding public-private partnership, providing comprehensive support to innovation and science development in the region, introducing actual social innovations, and unshadowing of the regional economy.

Results of analysing the structure of the expenditure part of the regional budget in the social sphere confirm the general tendencies of recent years in Ukraine, namely: a gradual reduction in the structure of expenditures on education (on average by $4.5 \%$ in the region) and expenditures on health care $(2.5 \%)$ and growth of expenditures on social protection and social security from $4.7 \%$ in the Odesa region to $7.4 \%$ in the Kherson region. At the same time, in the Mykolaiv region, some reduction in the expenditure structure of local budgets is observed for expenditures on social protection and social security $(-1.6 \%)$ and a significant increase in capital investment (10\%), which indirectly means an improvement in the economic situation in the region.

Thus, the urgent tasks of financing the social development of the region are:

- Determination of the main sources of financial support for social development, forecast of own revenues and expenditures;

- Determination of additional sources of financing of the social sphere;

- Outline of the priority directions of financing of social development and concentration of financial resources in these directions;

- Definition of the most effective methods of financial security;

- Formation of the system of financial relations.

The main basis of financing social guarantees of the population remains the regional budget, from which the funds are allocated for the provision of social benefits in protected articles. In this aspect, the leading factor in the effectiveness of the functioning of the regional social system is ensuring the efficiency and transparency of intergovernmental relations and the effective implementation of delegated powers in this area. However, the scarcity of budget funds does not allow solving the entire complex of specific social development problems facing each region. Therefore, an important task of regional authorities and local selfgovernment bodies is the search for additional sources of financing of the social sphere and the formation of mutually beneficial financial relations with potential "donors", as well as the development of alternative forms of provision of social assistance and social services. 
Table 3

Separate indicators of budget expenditures by regions of the Black Sea region per capita of the existing population, UAH

\begin{tabular}{|l|c|c|c|c|c|c|c|c|c|}
\hline \multirow{2}{*}{ Indicator } & \multicolumn{2}{|c|}{ Mykolaiv region } & \multirow{2}{*}{ Gain, \% } & \multicolumn{2}{c|}{ Odesa region } & \multirow{2}{*}{ Gain, \% } & \multicolumn{2}{c|}{ Kherson region } & \multirow{2}{*}{ Gain, \% } \\
\cline { 2 - 7 } & 2014 & 2016 & & 2014 & 2016 & & 2014 & 2016 & \\
\hline Expenditures on capital investments & 22,6 & 102,8 & 356 & 163 & 952 & 484 & 80,1 & 85,1 & 6,2 \\
\hline \% in the structure & 0,5 & 1,5 & 1,0 & 3,8 & 13,9 & 10,1 & 1,7 & 1,3 & $-0,5$ \\
\hline Expenditures on education & 1795,9 & 2507,2 & 39,6 & 1509,8 & 2026,3 & 34,2 & 1857,0 & 2463,6 & 32,7 \\
\hline$\%$ in the structure & 39,8 & 35,4 & $-4,3$ & 35,0 & 29,6 & $-5,4$ & 40,2 & 36,3 & $-4,0$ \\
\hline Expenditures on healthcare & 1049,7 & 1474,3 & 40,4 & 973,6 & 1331,5 & 36,8 & 1086,2 & 1457,1 & 34,1 \\
\hline \% in the structure & 23,2 & 20,8 & $-2,4$ & 22,6 & 19,5 & $-3,1$ & 23,5 & 21,4 & $-2,1$ \\
\hline Expenditure on social protection and social security & 1397,6 & 2519,7 & 80,3 & 1326,4 & 1990,3 & 50,1 & 1361,9 & 2509,2 & 84,2 \\
\hline \% in the structure & 30,9 & 35,6 & 4,7 & 30,8 & 29,1 & $-1,6$ & 29,5 & 36,9 & 7,4 \\
\hline Expenditures on housing and public utilities & 250,8 & 471,4 & 88,0 & 339,8 & 536,6 & 57,9 & 232,4 & 281,1 & 20,9 \\
\hline$\%$ in the structure & 5,6 & 6,7 & 1,1 & 7,9 & 7,8 & 0,0 & 5,0 & 4,1 & $-0,9$ \\
\hline Total expenditures, UAH & 4516,6 & 7075,4 & 56,7 & 4312,7 & 6836,4 & 58,5 & 4617,6 & 6796,1 & 47,2 \\
\hline
\end{tabular}

Source: calculated by the authors based on the data of the State Treasury Service

The main sources of extrabudgetary financing of the social sphere in the region, according to R. O. Maslyk, include:

- funds from non-governmental organizations and international target funds that operate for a certain purpose and perform certain social functions (protection of women, children, provision of certain rights and freedoms, development of creative potential, etc.). In our opinion, regional authorities and local self-government bodies should stimulate the opening of representative offices of such organizations in the region, which would contribute to solving a certain range of specific problems;

- charitable and volunteer organizations;

- stimulation of social entrepreneurship (Maslyk, 2014).

According to Bashynskyi, important areas for mobilizing financial resources and their distribution to improve the social situation in the region are:

- use of banking potential in the field of lending of priority social projects and participation in social programs of the region;

- regional support for the establishment of social enterprises and the organization of relevant social work; - use of the social potential of business based on the conclusion of relevant agreements;

- organization of public funding of individual social projects and programs (Bashynskyi, 2016).

Improving the financial mechanism of the socialization of the development of regions, in addition to finding additional sources of financing for the social sphere, also provides for the efficient allocation of financial resources, which will ensure balanced development of the social sphere of the region and promote active human development. Increasing the efficiency of the distribution of budgetary and extrabudgetary finance for the development of the social sphere requires the identification of their priority and an appropriate link to certain types of income. Thus, protected items of income are tied to revenues of the state budget and specialized funds (Social Insurance Fund and Pension Fund). Priority areas for financing from local budgets are also the maintenance of social infrastructure, health and education facilities. Together with this, the creation of regional programs is the tool for regulation and activation of social development of territories, as well as solving current social problems. In particular, it was investigated in the article that the main problems of the social development of the Black Sea region today are: worsening of demographic processes, increase of the incidence of the population, insufficient provision of conditions for the development of science and introduction of innovations, the gradual weakening of small business.

Accordingly, regional programs are necessary that will facilitate the correction of these processes. At the same time, social projects and programs of national importance or with specific direction should be financed by a variety of extrabudgetary sources. To this end, it is important to create appropriate conditions and formulate appropriate financial relationships based on: - activation of informational and propaganda work in the field of social development: meetings and roundtables with employers of the region, forums for potential investors;

- formation of the institute of regional guarantees for the development of social business and assistance in the creation of crowdfunding funds;

- expansion of opportunities for public discussion of acute social problems of territorial communities on the rights of participatory governance;

- creation of conditions for the development of nonprofit organizations and related funds;

- involvement of the scientific potential of the region in solving social and economic problems.

These measures require appropriate organizational and legal registration and reform of the system of regional management of the social sphere. 


\section{Conclusions and perspectives of further research}

The stable development of the social sphere of the Black Sea region requires such a level of financial support that would enable the social sphere to become one of the important factors in the transition to sustainable development of the economy as a whole. Characteristic feature of the social Black Sea region in recent years is the lack of both budget and extrabudgetary funding, which in turn negatively affects the development of financial infrastructure, low-quality provision of social services, and does not contribute to effective human development, which is not only the main goal but also the key determinant of the economic development of the region. Taking into account the current state and trends of socio-economic development of Ukraine, increasing the volume of budget financing in the near future is problematic, and in this connection, it is necessary to focus on finding additional sources and directions of extrabudgetary financing of social programs. In turn, for social institutions financed mainly at the expense of local budgets of different levels, it is expedient to expand autonomy in the field of attracting and using financial resources. This will allow not only attracting additional financial resources on their own but also spending them on the basis of their own needs and priorities of local importance.

Thus, the improvement of the financial mechanism of the socially-oriented model of development requires comprehensive justification and establishment of clear and transparent financial relations in the areas of income generation and distribution of expenditures of regional budgets at all levels, creation of conditions for additional attraction of financial resources from extrabudgetary sources aimed at the realization of regional social programs, and creation of an effective system for monitoring the functioning of the financial mechanism, primarily on the part of territorial communities.

\section{References:}

Bashynskyi, T. V. (2016). Mekhanizmy realizatsiyi sotsialnoyi polityky v systemi alternatyv finansovoho zabezpechennya [Mechanisms for implementing social policy in the system of alternatives to financial security] (phd Thesis), Khmelnytskyy Natsionalnyy Universytet.

Honcharuk, Y., Kushlak, A. (2012). Problematyka finansovoho zabezpechennya orhaniv mistsevoho samovryaduvannya [Problems of Financial Provision of Local Self-Government Bodies]. Ekonomichnyy analiz, 10(2), 206-209.

Zhuk, O. B. (2017). Finansovyy mekhanizm systemy sotsialnoho zakhystu naselennya Ukrayiny [Financial mechanism of the system of social protection of the population of Ukraine]. Svit finansiv, 2(51), 62-71.

Kabinet Ministriv Ukrayiny (2017). Pro reformu tsentralizatsiyi [About the decentralization reform]. Retrieved from: http://decentralization.gov.ua/about (accessed 19 June 2018)

Maslyk, R. O. (2014). Finansovyy stan sotsialnykh prohram yak instrumentiv zdiysnennya sotsialnoho zakhystu naselennya Ukrayiny [Financial state of social programs as tools of social protection of population of Ukraine]. Tekhnolohycheskyy audyt y rezervy proyzvodstva, 5/3(19), 56-59.

Mykolayivska oblasna rada. Retrieved from: https://www.mk-oblrada.gov.ua/document-list.php?group_id=184 (accessed 19 June 2018)

Odeska oblasna rada. Retrieved from: http://oblrada.odessa.gov.ua/odeska-oblast/byudzhet-odeskoyi-oblasti (accessed 19 June 2018)

Ofitsiynyy sayt derzhavnoyi kaznacheyskoyi sluzhby Ukrayiny. Retrieved from: http://www.treasury.gov.ua/ main/uk/index (accessed 19 June 2018)

Pihul, N., Boiko, A. (2015). Finansove zabezpechennya sotsialnoyi sfery v Ukrayini [Financial Support to the Social Sphere in Ukraine]. Visnyk Natsionalnoho banku Ukrayiny, 1, 30-35.

Stepanova, O. V. (2016). Finansuvannya sotsialnoho zakhystu v umovakh detsentralizatsiyi: zarubizhnyy dosvid ta natsionalni realiyi [Financing social protection in conditions of decentralization: foreign experience and national realities]. Investytsiyi: praktyka ta dosvid, 22, 73-79.

Khersonska oblasna rada. Retrieved from: http://khor.gov.ua/hersonshhina/oblasniy-byudzhet-na-2017-rik/ (accessed 19 June 2018)

Shcherbakova, O.L. (2012). Finansove zabezpechennya sotsialno-ekonomichnoho rozvytku monofunktsionalnoho mista [Financial support of socio-economic development of a monofunctional city] (phd Thesis), Zaporizhzhya.

Irtyscheva, I. A., Khvesyk, J. M., Stehnei, M. I. (2015). Detsentralizatsiia systemy upravlinnia v zabezpechenni staloho rozvytku silskykh terytorii [Decentralization of management system in ensuring sustainable development of rural territories]. Ekonomika APK, 4, 64-70. 